\title{
Retrofitting the Suburbs: Insulation, Density, Urban Form and Location
}

\author{
Anne-Françoise Marique (Corresponding author) \\ University of Liege (Belgium), Architecture and Urban Planning \\ Local Environment: Management \& Analysis (LEMA), \\ Chemin des Chevreuils, 1 B52/3 B-4000 Liège (Belgium) \\ Tel: 32-4366-9367 E-mail: afmarique@ulg.ac.be

\begin{abstract}
Sigrid Reiter
University of Liege (Belgium), Architecture and Urban Planning

Local Environment: Management \& Analysis (LEMA),

Chemin des Chevreuils, 1 B52/3 B-4000 Liège (Belgium)

Tel: 32-4366-2909 E-mail: Sigrid.Reiter@ulg.ac.be
\end{abstract}

Received: September 30, 2014 Accepted: October 13, 2014

doi:10.5296/emsd.v3i2.6589 URL: http://dx.doi.org/10.5296/emsd.v3i2.6589

\begin{abstract}
The effects of urban sprawl have been well documented, particularly regarding energy consumption. Suburban neighbourhoods are known to be energy inefficient and urban sprawl is considered as a major issue for sustainable development. To improve the energy efficiency of existing suburban urban fabrics is a major challenge that must be addressed to favour a sustainability transition of our built environment. In this context, this paper aims at investigating several scenarios that could be developed to improve the sustainability of existing suburban neighbourhoods: three main types of scenarios (building insulation, density, and urban form) and twelve sub-scenarios, which are focused on the possible evolution of the existing suburban building stocks, are proposed. Quantitative methods developed in previous research are used to assess and compare building and transportation energy consumption of a representative suburban case study. This application aims at investigating two main research questions: (1) "how to intervene in suburban neighbourhoods?" and (2) «where to intervene?" The main results of this application, which are focused on energy efficiency, are then studied in
\end{abstract}


a larger framework to highlight their opportunities and constraints. The main findings of the paper are that, beyond the traditional polarisation of the debates on the energy efficiency of our built environment between the "compact" and the "sprawled" city, a new pragmatic paradigm, which is focused on the smooth densification of existing suburban neighbourhoods, can make them evolve towards greater sustainability.

Keywords: Urban Sprawl, Suburban retrofitting, Energy efficiency, Urban form, Smooth densification

\section{Introduction: Urban Sprawl and Energy Efficiency in Urban Planning}

The process of urban sprawl, which commonly describes physically expanding urban areas, is a major issue for sustainable development (EEA, 2006). Urban sprawl is known to represent a significant contribution to the overall energy consumption of a territory, particularly for energy needs in buildings and for transport. The environmental effect of urban sprawl and uncontrollable urbanisation are receiving an increasing amount of attention and may lead to various issues such as environmental pollution or large-scale climate change (CPDT, 2002; He et al., 2011; UTF, 1999; Young et al., 1996). However, despite the growing importance of energy issues in public debate, low-density suburban developments continue growing regardless of their location. Even new districts that set themselves up as "eco" or "sustainable" are sometimes built far from city centres and are not necessarily ecological because of the high transport energy consumption (Harmaajärvi, 2000). Such developments are found all over Europe, the United States and even emerging countries (Nesamani, 2012; da Silva et al., 2007; Yaping and Min, 2009)and have become an important part of our contemporary metropolitan areas (Phelps, 2012). An evaluation on the sustainability of these suburban neighbourhoods is necessary and requires the appropriate methods and tools.

The problems of urban sprawl and its numerous environmental, economic and societal effects inevitably refer to the question of "urban form" and its densities and, in particular, the validity of two prevailing and opposite models: the "compact city" and the "sprawled city". The opponents of sprawl articulate the "compact city" model in opposition to the "sprawled city" model using the concepts of centrality, high density, mixed use and performing urban transportation systems. Numerous authors argue that more compact urban forms will significantly reduce the energy consumption in both the building and the transportation sectors (e.g., Ewing et al., 2008; Gillham, 2002; Newman and Kenworthy, 1989 and 1999; Riera and Rey, 2013; Steemers, 2003). However, the concrete feasibility of this model, which is often presented as an ideal urban form, is questionable. In fact, numerous research studies and policies at the national, regional and local levels pretend that it is crucial to favourthe compactness of cities and to thwart urban sprawl but do not propose adequate tools or policies to meet these goals. Moreover, several effects that are related to high compactness (such as congestion, pollution, increase of land prices, etc.) are not adequately addressed. In addition, in numerous European countries, the renewal rate of the building stock is notably low (1 to $2 \%$ per year), which implies that the main challenge is this existing building stock and its transition towards greater energy efficiency and greater sustainability. More problematically, this model does not propose any solution for the existing suburban building stock. 
The "sprawled city" model dates back from the 19th century and was first developed to reduce the use of urban soil and the production prices. Because the transport costs rapidly declined and the travel speed increased (Ewing, 1994), the mobility levels per capita have substantially increased over the recent past and have favoured the development of suburban neighbourhoods. The sprawl is believed to be facilitated by car ownership and use and to contribute to them in a positive feedback loop that reinforces both low-density development and motorisation (Gilbert and Perl, 2008). Ewing (1994) and Urban Task Force (1999) also defined sprawl in terms of "undesirable" land-use patterns. However, if some authors are clearly critical of suburbs, others propose a more critical conversation (Modarres, 2009). Sprawl often induces lower land prices and more affordable housing (Gordon and Richardson, 1997). The low-density developments mean more space and a higher standard of living for numerous households and constitute one of the preferred living accommodations (Berry and Okulicz-Kozaryn, 2009; Couch and Karecha, 2006; Gordon and Richardson, 1997; Howley, 2009). However, the promotion of this development model even at notably high construction standards (low energy or passive standards that limit the heating energy requirements of buildings at 60 and $15 \mathrm{kWh} / \mathrm{m}^{2}$.year, respectively) will not help to solve numerous problems that are related to urban sprawl, such as soil waterproofing, car dependency or the costs of infrastructure, networks and services.

Three main types of strategies could be investigated to limit the urban sprawl at the regional / national level. The first strategy could consist in an adaptation of the urban planning regulation framework to prohibit the urbanisation of new suburban neighbourhoods in a plain area. However, this strategy seems unrealistic because of its numerous financial consequences (compensation for depreciation, etc.). Moreover, this strategy is only efficient at a large (national) scale. The second strategy, which is often mobilised in the current policies, favours the urban renewal of city centres to propose dwellings that are better adapted to the new comfort and insulation standards (houses with gardens for families, etc.) The third strategy that could be developed follows the same goal as the previous one and consists in building new sustainable neighbourhoods located near good transportation hubs, with have attractive green and public spaces, high quality of life, etc. These last two scenarios could favour a soft transition of our built urban environment towards greater sustainability, but there is one major limitation: they do not consider the future and the possible evolutions of the numerous existing suburban neighbourhoods.

There are intervention scenarios for the existing suburban neighbourhoods to adapt them to climate change, which have been recently developed in the literature, particularly in the United States of America, the United Kingdom and Australia (e.g., Dunham-Jones and Williamson, 2011; Modarres and Kirby, 2012; Rice, 2012; Tachieva, 2012; Williams et al., 2013). These authors propose concrete approaches, at the local level, to retrofit suburbs and increase their sustainability. Amongst various approaches (e.g., an increase in the diversity of functions, good public transportation, a retrofitting of existing networks to increase walking), an increase in the density of both people and uses is often presented as the key means for success. In France, the intensification of suburban areas is also an emerging research topic. A recent French research was dedicated to the issue of Bimby, or "Build In My Back Yard" (Miet and Le Foll, 2013) and specifically proposed to exploit the large land resources available in suburban gardens to 
accommodate new dwellings. Since the first works on this issue of residential developments in gardens (Whitehand et al., 1991), and despite its potential for suburban intensification and urban compactness, this topic remains relatively little-researched (Sayce et al., 2012). Moreover, and more generally speaking, although one of the main aims of the approaches developed to retrofit suburban areas is to increase their sustainability, their energy efficiency is not evaluated.

In this context, this paper investigates the necessary conditions to improve the energy efficiency of existing suburban areas, by focusing on the impact of urban planning on building and transport energy consumptions at the neighbourhood scale. The following sections present (1) three main retrofitting scenarios that can be investigated to favour this evolution of suburban areas, (2) a quantitative method to assess the energy efficiency of these scenarios regarding thebuilding and transport energy consumptions at the neighbourhood scale, (3) its application to one representative neighbourhood in Belgium and (4) the confrontation between these results, focused on the energy efficiency, with the required practical conditions to achieve the proposed scenarios, such as the regulation framework, the cost and the social acceptability of the proposed measures. Finally, our main findings are summarised to conclude the paper and offer perspectives for further study onsustainability, energy efficiency and retrofitting in the suburbs.

\section{Retrofitting Scenarios}

In this paper, three main scenarios that address a possible evolution of these existing suburban neighbourhoods are investigated and assessed. These scenarios address the characteristics of buildings and urban form. They do not address parameters that are not directly linked to urban planning. The behaviour of the inhabitants, that is known to have a significant impact on energy consumption, is not discussed in this paper that focused on urban form. The behaviour of the inhabitants in suburban houses has been extensively studied in a previous paper (de Meester et al., 2013).

\subsection{Improving the Insulation of the Existing Suburban Building Stock}

The first scenario improves the insulation of the existing suburban building stock without any other intervention on the urban form of the existing neighbourhoods (thus, it maintains their characteristics in terms of the density, the diversity of functions, etc.). These scenarios are identified in the following of this paper by the letter "A". Five sub-scenarios are defined to capture different levels of intervention: A1 -insulating the roof with 20 centimetres of mineral wool, A2 -insulating the roof and replacing the glazing, A3 -retrofitting the entire envelope to fit the actual energy requirements for new buildings, A4 and A5 -retrofitting the entire building envelope to satisfy the low-energy (heating requirements $<60 \mathrm{kWh} / \mathrm{m}^{2}$.year) and the passive (heating requirements $<15 \mathrm{kWh} / \mathrm{m}^{2}$.year) standards, respectively.

\subsection{Increasing the Built Density of Existing Suburban Neighbourhoods}

The second scenario addresses an increase in the built density of the existing neighbourhoods by constructing new houses or apartments in the gardens, where land opportunities are available. There are identified by the letter " $\mathrm{B}$ " in the following of the paper. Four 
sub-scenarios are defined. In B1, new dwellings are built on the remaining unoccupied plots. In B2, the existing plots are divided to construct new dwellings at the bottom of the plots. In B3, new dwellings (detached houses) are built among the existing houses.In B4, new dwellings (terraced houses) are built among the existing houses. These four sub-scenarios are illustrated on Figure 1.
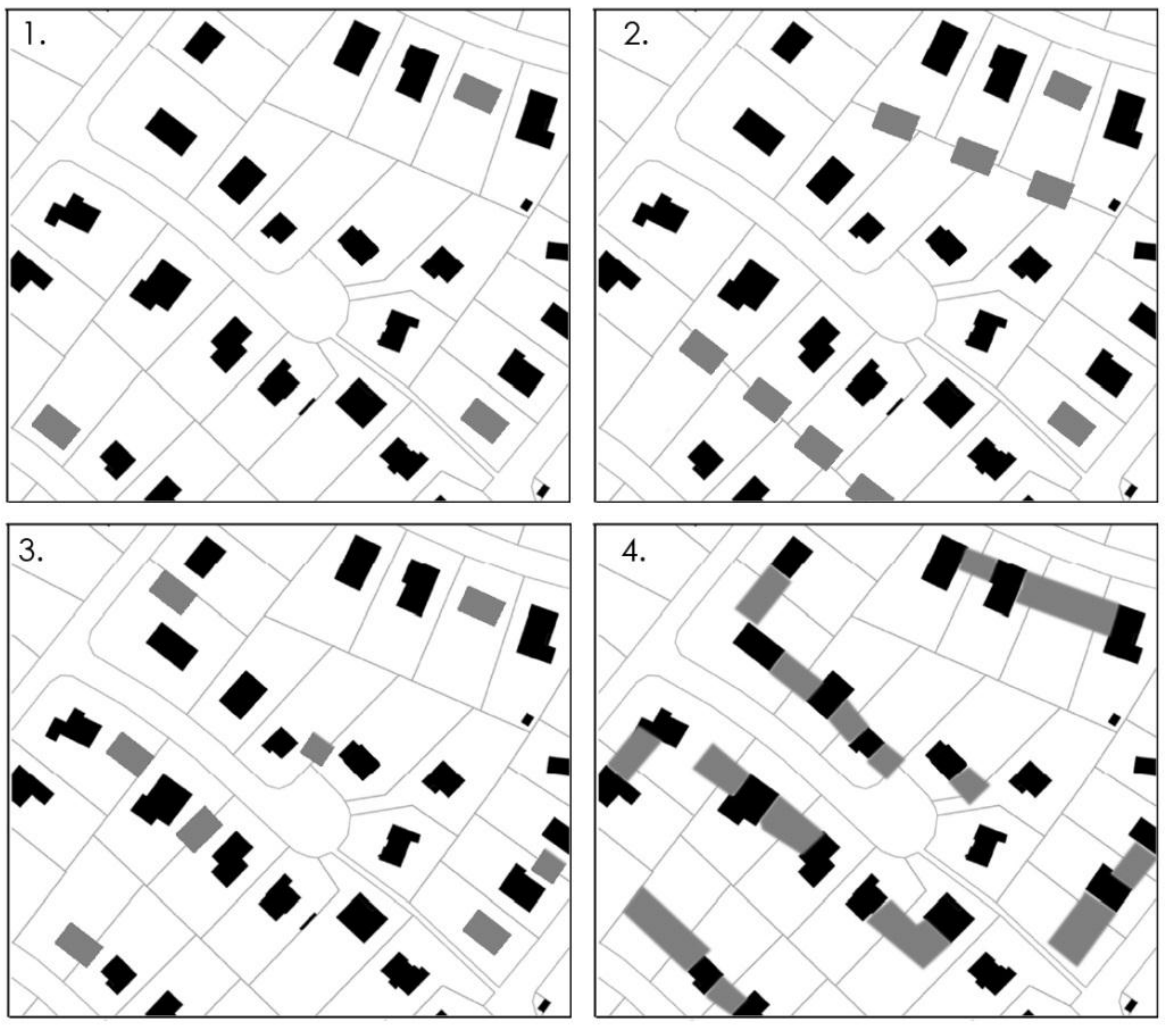

Figure 1. Illustration of the four sub-scenarios that increase the built density of the existing suburban neighbourhoods thanks to the construction of new dwellings in the gardens (the existing houses are in black, and the new dwellings are in grey). In B1, new dwellings are built on the remaining unoccupied plots. In B2, the existing plots are divided to construct new dwellings at the bottom of the plots. In B3, new dwellings (detached houses) are built among the existing houses. In B4, new dwellings (terraced houses) are built among the existing houses.

\subsection{Re-Building More Compact Suburban Neighbourhoods}

The third scenario is the most theoretical because it implies to demolish existing neighbourhoods and to re-build new neighbourhoods. It investigates the energy efficiency of more compact urban forms than the "detached houses". This scenario is proposed because it allows the comparison between low-density suburban neighbourhood and more compact urban forms, for one fixed level of insulation, the same number of dwellings and the same built surface area. Scenarios dealing with urban form are identified by the letter " $C$ " in the following of the paper. $\mathrm{C} 1$ is the reference case; the urban form of the suburban neighbourhood remains unchanged (the detached houses are built on large individual plots), but the houses are built 
according to the actual European standard for new buildings, which includes the energy requirements. Two more sub-scenarios are defined. In these sub-scenarios, the number of dwellings and the built surface area remain constant; however, in C2, the dwellings are terraced houses (ground floor +1 floor) that are organised in the traditional urban blocks, whereas in $\mathrm{C} 3$, the dwellings are collective apartment buildings (ground floor +2 or 3 floors) as illustratedin Figure 2. In the sub-scenarios C2 and C3, the dwellings are built according to the actual standard for new buildings regarding the energy requirements for heating.
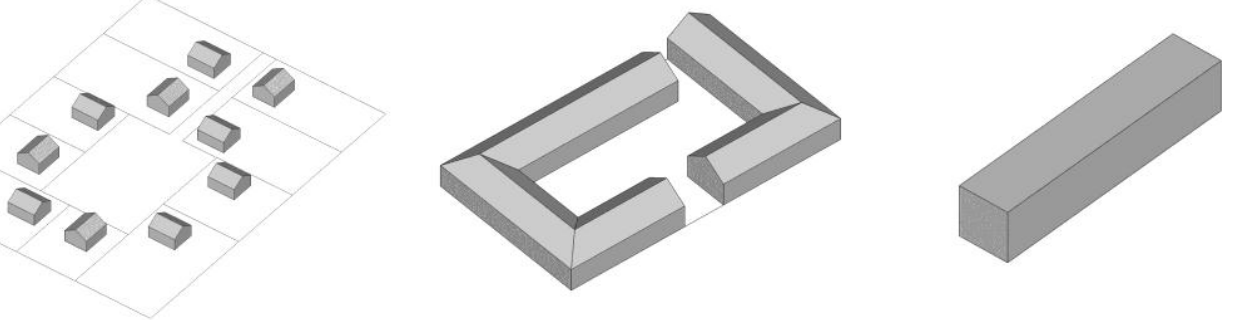

Figure 2. Schematic representation of the reference case and the two sub-scenarios dealing with more compact urban forms. Sub-scenario C1 (illustrated on the left of this image) $\mathrm{C} 1$ is the reference case; the urban form of the suburban neighbourhood remains unchanged (the detached houses are built on large individual plots), but the houses are built according to the actual European standard for new buildings, which includes the energy requirements. In sub-scenario C2 (middle), the dwellings are terraced houses (ground floor +1 floor) that are organised in the traditional urban blocks, whereas in sub-scenario C3 (right), the dwellings are collective apartment buildings (ground floor +2 or 3 floors).

\section{Method and Assumptions}

A method was developed to evaluate the energy consumption of the suburban neighbourhoods and the retrofitting scenarios. The first part of the method, which calculates the energy requirements of the buildings and the assumptions that were used are extensively presented in Marique and Reiter (2012a). The methodology combines a typological classification of buildings (based on the common ownership, the number of level and the surface area of the dwelling; see also Marique and Reiter (2012a) for more details), thermal dynamic simulations and statistical treatments of national censuses to assess the annual energy consumption for space heating, space cooling, ventilation, appliances and domestic hot water. The energy consumption and the primary energy consumption for space heating, cooling and ventilation at the neighbourhood scale are calculated by adding the results from the energy simulations for each type of house according to their distribution in the neighbourhood. The energy consumptions of the appliances, for cooking and domestic hot water are not considered in the framework of this paper. Note also that empirical surveys (ICEDD, 2005; Kint, 2008) show that heating represents the largest portion of the overall energy consumption of Belgian households $(76 \%)$.

The second part of the energy assessment addresses the energy consumption for daily mobility, which is assessed using a commute-energy performance index that was developed by Boussaux and Witlox (2009) and adapted by Marique and Reiter (2012b) for suburban areas. 
Assumptions taken into account for the Belgium context were presented extensively in Marique and Reiter (2012b). This index is expressed in $\mathrm{kWh} /$ travel.person and represents the mean energy consumption per territorial unit for travel for one person who lives within a particular neighbourhood. This index considers the travelled distances, the means of transport and its relative consumption rates, which are expressed by equation (1). This index was calculated and mapped for the whole Belgium territory, using a GIS tool, at the "census block" scale. In Belgium, the "census block" (or neighbourhood) is the smaller territorial unit in which statistical data are available.

$$
\text { Energy performance index }(i)=\sum_{m} \frac{D_{m i} \cdot f_{m}}{T_{i}}
$$

In equation (1), $\mathrm{i}$ is the territorial unit, $\mathrm{m}$ is the mean of transport (diesel car, fuel car, train, bus, bike, on foot), Dmi is the total distance travelled using the means of transport $m$ in the district $i, f m$ is the consumption factor attributed to the means of transport $m$, and $T i$ is the number of persons in the territorial unit $i$. The consumption factors depend on the consumption of the vehicles (litres of fuel per kilometre) and their occupancy rate. The indices are 0.56 $\mathrm{kWh} /$ person.km for a diesel car, $0.61 \mathrm{kWh} / \mathrm{p} . \mathrm{km}$ for a gasoline car, $0.45 \mathrm{kWh} / \mathrm{p} . \mathrm{km}$ for a bus, $0.15 \mathrm{kWh} / \mathrm{p} . \mathrm{km}$ for a train and 0 for non-motorised means of transportation because they do not consume any energy in the following application but can be adapted to each situation and territory because their calculation is entirely parameterised.

The energy consumption for the daily mobility is obtained via equation 2 .

$$
E_{D M}=\text { Energy performance index } * N \times T
$$

In equation 2, the energy performance index is multiplied by the number of people $N$ and the number of trips $T$ in the neighbourhood.

Note that these data only consider the home-to-work and home-to-school travels, but we can use the same methodology for in situ survey data to consider all travel purposes. Although the home-to-work and home-to-school travels are becoming less meaningful in the daily travel patterns in the Western world because of the dramatic growth in other activities (Graham, 2000; Pisarski, 2006), they have more structural power than other travel forms because they are systematic and repetitive.

Using the developed method, the building energy consumption and the transportation energy consumption can be expressed with a common unit (kWh/person.year or $\mathrm{kWh}$ /neighbourhood.year), which allows one to consider these two topics together and to include the effect of the location on the daily mobility in the energy balance.

\section{Application and Results}

Urban sprawl is a concern in a large portion of Wallonia (Belgium). In this region, 52\% of the building stock is detached and semi-detached houses (Kints, 2008), and 50\% of the census 


\section{$\triangle$ Macrothink}

blocks of the region has a mean housing density between five and twelve dwellings per hectare (Vanneste et al., 2007). Suburban neighbourhoods are found everywhere in the region and not only in the suburban municipalities. In this case study, the aforementioned method is applied to one representative suburban neighbourhood of Wallonia. This representative neighbourhood (Figure 3) was selected based on a typological classification of neighbourhoods that was performed to highlight the most representative type of suburban neighbourhoods. Numerous simulations, calculations and sensitivity analyses were performed on several representative neighbourhoods and highlighted that the major trends (highlighted below) remain the same for the suburban neighbourhoods, which shows a built density of 5-12 dwellings per hectare (Marique, 2013).

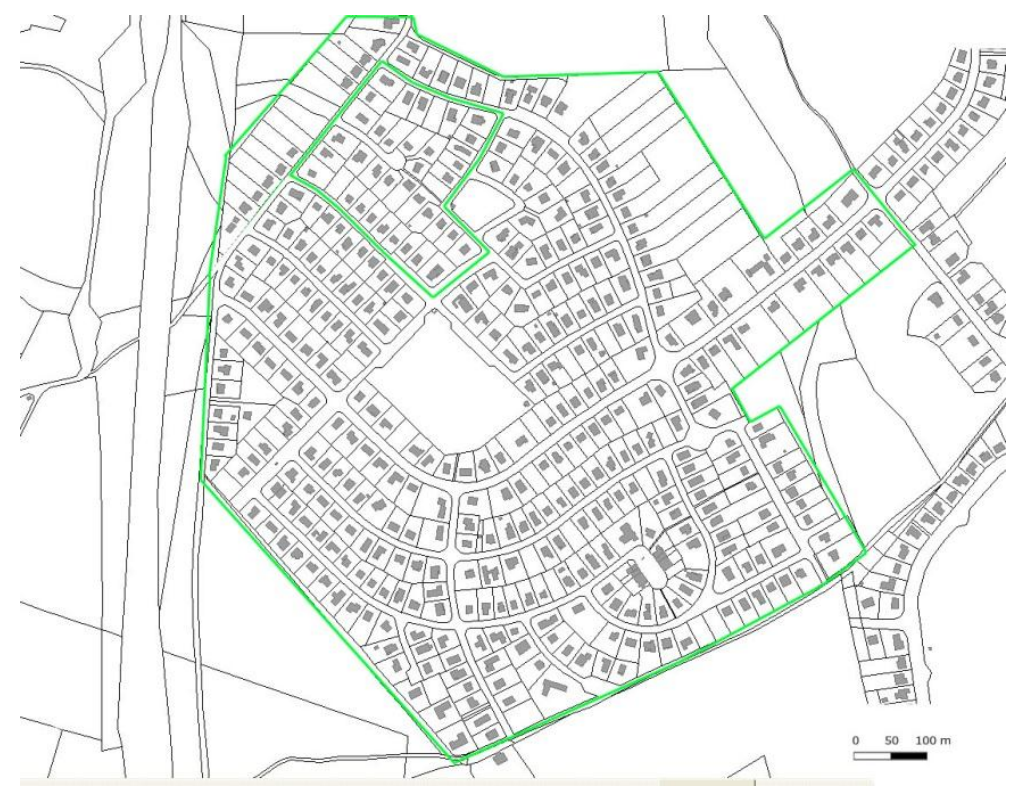

Figure 3. The selected representative suburban neighbourhood

Currently, the required energy for heatingin buildings is the most important portion of the calculated consumption at the neighbourhood level because the existing suburban building stock in Wallonia is old and poorly insulated. Depending on the available bus services and the distance to the city centre, transportation (only home-to-work and home-to-school travels are considered) represents $11.9-35.9 \%$ of the energy consumption of a neighbourhood.

Then, the aforementioned twelve sub-scenarios were applied to this representative neighbourhood to investigate their energy efficiency. Quantitative results are summarized in Table 1 and show that, from an energy viewpoint, all scenarios present interesting results. As stated in Table 1, the energy consumption for heating in buildings is reduced by $-7.3 \%$ (if only the roofs of the existing buildings are insulated) to $-89.8 \%$ (if passive retrofitting is promoted). For one fixed insulation level (e.g., the actual fixed energy requirements in the European Directive on the Energy Performance of Buildings as presented in Table 1, although the trends are identical for the low-energy and the passive standards), the most efficient strategies rebuild the neighbourhoods in a more compact urban form (urban blocks or apartment buildings). These scenarios allow a reduction of $68.1 \%$ and $70.4 \%$, respectively, in comparison with the 
reference case (detached houses; related to a reduction of $45.2 \%$ only), which highlight the low energy efficiency of this type of urban form, even when the detached houses have better insulation (the result is also true for identical insulation levels). An increase in the built density of the existing neighbourhoodsalso improves the energy efficiency of the existing neighbourhoods by constructing new well-insulated houses (B1 to B3). In B4, the results are better because the insulation of new buildings and the building distribution (terraced houses) are mobilised together. Another interesting scenario, which is assimilated into B4, is the building of new collective dwellings in existing neighbourhoods where large land opportunities remains available (for example, in the centre of suburban blocks that were only urbanised on their perimeter). To optimise the energy consumption reductions of the scenarios that increase the built density, it appears necessary to also improve the insulation of the existing buildings. Beside their interest in terms of the energy efficiency, the scenarios that increase the built density avoid the urbanisation of unoccupied land and the construction of new infrastructures.In these scenarios, the new dwellings are developed by increasing the density of the existing neighbourhoodsinstead of developing new low-density neighbourhoods.

Table 1. Reductions in energy consumption for heating in buildings, which were obtained for twelve retrofitting scenarios

\begin{tabular}{|c|c|c|c|c|c|}
\hline \multicolumn{2}{|c|}{ A.INSULATION } & \multicolumn{2}{|c|}{ B.BUILT DENSITY } & \multicolumn{2}{|c|}{ C.URBAN FORM } \\
\hline Scenarios & $\begin{array}{l}\text { Energy } \\
\text { consumption } \\
\text { reductions }\end{array}$ & Scenarios & $\begin{array}{l}\text { Energy } \\
\text { consumption } \\
\text { reductions }\end{array}$ & Scenarios & $\begin{array}{c}\text { Energy } \\
\text { consumption } \\
\text { reductions }\end{array}$ \\
\hline $\begin{array}{l}\text { A1.Insulation in the } \\
\text { roofs }\end{array}$ & $-7.3 \%$ & $\begin{array}{l}\text { B1.Unoccupied } \\
\text { plots }\end{array}$ & $-5.2 \%$ & $\begin{array}{l}\text { C1.Detached } \\
\text { houses }\end{array}$ & $-45.2 \%$ \\
\hline $\begin{array}{l}\text { A2.Insulation in the } \\
\text { roofs + double } \\
\text { glazing }\end{array}$ & $-14.8 \%$ & $\begin{array}{l}\text { B2.Bottom of the } \\
\text { plots }\end{array}$ & $-17.4 \%$ & $\begin{array}{l}\text { C2.Urban } \\
\text { blocks }\end{array}$ & $-68.1 \%$ \\
\hline $\begin{array}{l}\text { A3. Retrofitting to } \\
\text { actual standard }\end{array}$ & $-45.2 \%$ & $\begin{array}{c}\text { B3.Detached houses } \\
\text { between existing } \\
\text { houses }\end{array}$ & $-12.9 \%$ & $\begin{array}{l}\text { C3.Apartment } \\
\text { buildings }\end{array}$ & $-70.4 \%$ \\
\hline $\begin{array}{c}\text { A4.Retrofitting } \\
\text { to the low-energy } \\
\text { standard }\end{array}$ & $-59.2 \%$ & $\begin{array}{c}\text { B4.Terraced houses } \\
\text { between existing } \\
\text { houses }\end{array}$ & $-30.4 \%$ & & \\
\hline $\begin{array}{l}\text { A5.Retrofitting to } \\
\text { the passive standard }\end{array}$ & $-89,8 \%$ & & & & \\
\hline
\end{tabular}

However, the previous scenarios, particularly those that address the density and the construction of new urban forms, cannot be recommended everywhere in the territory. It is crucial to consider the effect of the location of the neighbourhoods on the travelled distances and the transport energy consumption. For example, the building of a mixed and dense neighbourhood andthe increase in density of an existing neighbourhood that is notably badly located (far from the city centre, shops and other services, with notably low bus services) are obviously counter-productive. Thus, the effect of the location of the neighbourhoods was finally investigated using the commute-energy performance index. Marique et al. (2013a; 2013b) highlighted the huge effect of the structure of the territory on the transport energy consumption (Figure 4). In this work, the territory is interpreted as the system defined by three main elements: i) the location of work places and services (commercial, education, leisure, etc.), ii) the spatial distribution of the population according to the place of residence and iii) the 


\section{Macrothink}

infrastructures (the transport and technical networks). The variation of functions (residences, shops, work places, leisure, etc.) in the neighbourhood and the built density have the strongest effect on the variation of the transport energy consumption. The energy efficiency of home-to-work and home-to-school trips is strongly determined by the travelled distance. The mode choice has a smaller effect on the energy performance of those types of commutes. This result can partly be explained by the relationship between the distance and the mode choice.

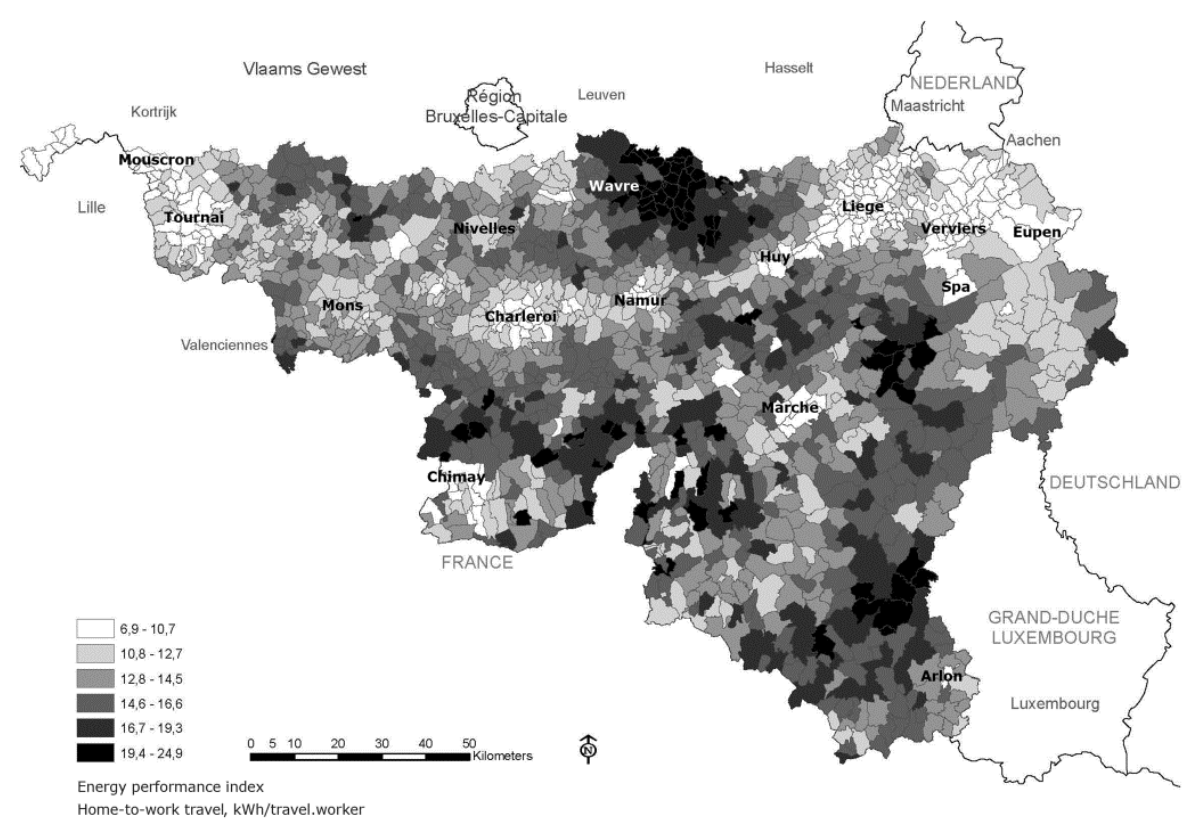

Figure 4. The mapping the commute-energy performance index for home-to-work travel (in $\mathrm{kWh}$ /person.travel at the neighbourhood scale shows the variation of the transportation energy consumption (home-to-work travel) according to the location of the neighbourhood.

In this work, these results are mobilised to identify the most appropriate suburban neighbourhoods, where an increase in the built density could be favoured without increasing the energy performance index for commuting. Because suburban neighbourhoods are mainly mono-functional and less dense, this simulation is based on the proximity between one suburban neighbourhood and one or more rural or urban cores, which are dense and present a great variety of functions. The urban and rural cores that we used are defined by the National Institute for Statistics (INS, 2006). Figure 5 highlights in yellow the most appropriate suburban neighbourhoods. The green suburban neighbourhoods are located further from the existing urban or rural cores. In those neighbourhoods, an increase in the built density and the construction of new neighbourhoods is not recommended; because of their location and characteristics, the transport energy consumption is expected to be high (longdistances to travel and few or no alternatives to private cars). 


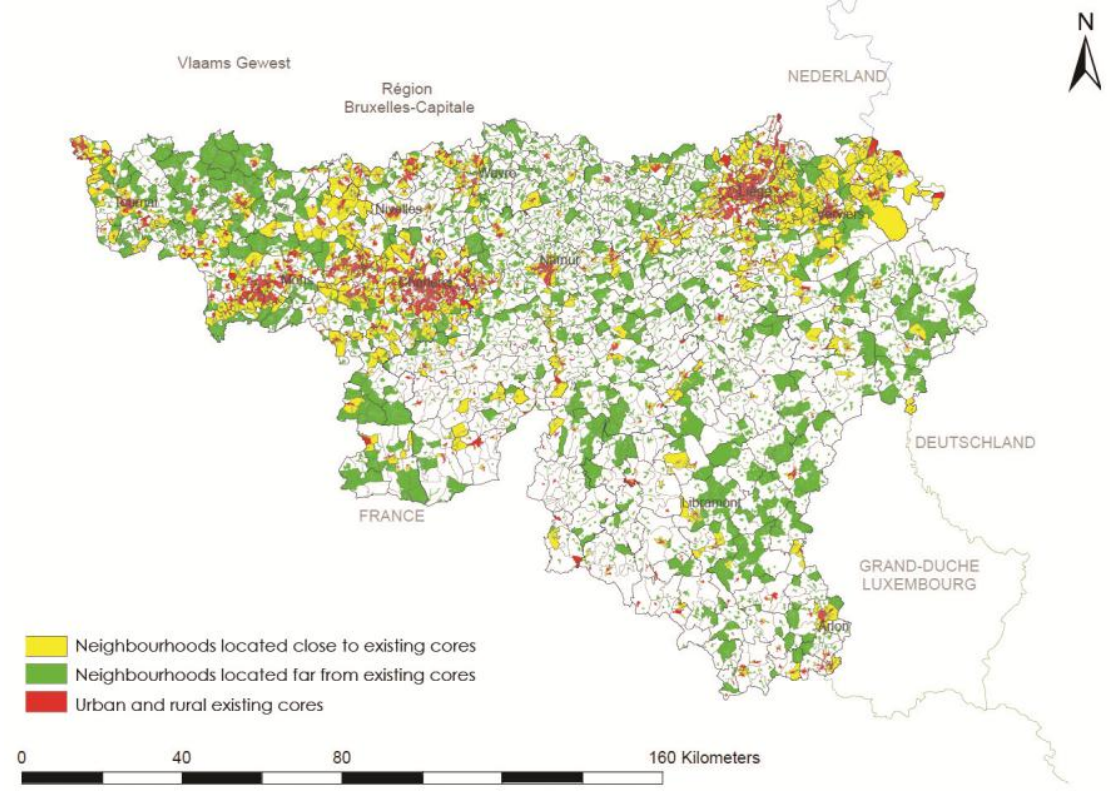

Figure 5. The urban and rural cores (in red), suburban neighbourhoods that are near an urban/rural core (in yellow) and suburban neighbourhoods that are far from the existing cores (in green).

Thus, the scenarios that increase the built density, as well as the building of new neighbourhoods, can be limited to these high-potential areas (neighbourhoods highlighted in yellow on Figure 5). Moreover, these two types of scenarios allow us to recompose locally dense and mixed cores, which have proved their interest in energy efficiency and mode choice in transportation (Marique et al., 2013a, Myung-Jung et al., 2013). This opportunity is interesting particularly because the regional administration has evaluated that 350,000 new dwellings will be built by 2040 to absorb the forecasted demographic growth $(+600,000$ inhabitants in Wallonia for 2040).

\section{Discussion: Retrofitting the Suburbs by Improving Their Energy Efficiency; Key Challenges and Limitations}

The results in the first parts of this paper were focused on the energy consumption, which is a crucial topic in the scope of a sustainability transition of suburban areas. This approach is finally completed and moderated by considering the previous study in a broader framework, which considers the economic feasibility of the proposed measures, the regulation framework that allows or does not allow these measures and its societal acceptability.

The cost of the works related to the sub-scenarios that address the insulation of existing buildings increased the insulation level increase (thus, the energy efficiency increase) because of the huge quantity of material to use to reach efficient energy standards. The return on investment must be studied in every particular case to refine this trend. Although there have been financial intensives for several years, this aspect is a major brake to the energy retrofitting of the existing building stock. The division of the existing large plots (mean size $=1,000 \mathrm{~m}^{2}$ ) to increase the built density of the existing neighbourhoods allows the owners to sell a part of their plot and gain a considerable amount of money. This option, also investigated in the French 
BIMBY research (Miet and Le Foll, 2013) is particularly interesting for households that do not use their entire plot.

We have studied the existing regulation framework (regional and local codes and rules that are related to architecture and urban planning) in Wallonia (Belgium) and this framework is adapted to the scenarios that address the insulation of existing buildings. The only possibly problematic element is the replacement of the facing materials (some colours and materials must be respected according to the local regulations). To increase the built density of existing neighbourhoods is more complicated (except in the sub-scenario B1) because most suburban municipal authorities are reticent to this trend and have adopted specific regulations to avoid increasing the built density of the existing and new suburban neighbourhoods. Because the densification of the existing low-density neighbourhoods is a major preoccupation of the actual regional government (urban planning is a regional matter in Belgium), we can hope for an evolution towards more flexibility in the next few years. Moreover, if the increase in the built density in scenario B1 to scenario B4 can be based on the individual initiatives, scenarios C1 to $\mathrm{C} 3$ and the densification of large unoccupied plots in the centre of the existing neighbourhoods request an important intervention of public authorities and private developers to manage the aspects linked to the land properties and build collective development (with various functions, etc.).

Finally, the societal acceptability of the scenarios that increase the built density is also notably problematic. As previously highlighted in the literature, a recent in situ survey in Wallonia (Pierson, 2010) confirms that households in those low-density suburban neighbourhoods are quite reticent to any changes, particularly to increase the built density. Further applied research dedicated to the social representations of housing is necessary to overpass this huge brake.

\section{Conclusions and Perspectives}

This paper addresses the challenges and conditions of a retrofitting of suburban areas, which was articulated around an increase in the energy efficiency in both the building and the transportation sectors. Two powerful levers were used: (1) urban form, which was considered in addition to the individual building scale, and (2) mobility, to consider the energy used in transportation. Three main types of scenarios (the retrofitting of existing neighbourhoods, increasing the built density and more compact urban forms) and twelve sub-scenarios focused on possible evolutions of the existing suburban building stock were modelled and assessed. The main results of this approach, which were focused on the energy efficiency, were then rethought in a larger framework to highlight the opportunities, the limitations, the constraints and the feasibility of each strategy. These findings show that beyond the traditional polarisation of the debates on energy efficiency of our built environment between the "compact city" and the "sprawled city", a new pragmatic paradigm, focused on the sustainability transition of suburban areas, particularly by smooth densification in the gardens of existing houses, can make suburban areas evolve towards greater sustainability. However, there are numerous brakes, particularly those that are related to the existing regulation framework and the societal acceptability of an increased density, which should be investigated in further study to be surpassed. These results open avenues for further research on the smooth densification in the 
suburbs (e.g., energy supply, renewable energy, water heating, ICT).

\section{Acknowledgement}

This paper presents the main results of research that was funded by the Walloon region of Belgium in the framework of the "Suburban Areas Favouring Energy efficiency" (SAFE) and the "Solutions for Low Energy Neighbourhoods" (SOLEN) research projects.

\section{References}

Berry, B., \& Okulicz-Kozaryn, A. (2009). Dissatisfaction with city life: A new look at some old questions. Cities. 26, 117-124. http://dx.doi.org/10.1016/j.cities.2009.01.005

Boussauw, K., \& Witlox, F. (2009).Introducing a commute-energy performance index for Flanders.Transportation Research Part A. 43, 580-591. http://dx.doi.org/10.1016/j.tra.2009.02.005

Couch, C., \& Karecha, J. (2006). Controlling urban sprawl: Some experiences from Liverpool. Cities. 23(5). 353-363. http://dx.doi.org/10.1016/j.cities.2006.05.003

CPDT. (2002). Les coûts de la désurbanisation. Namur: Conférence Permanente du Développement Territorial.

Dunham-Jones, E., \& Williamson, J. (2011).Retrofitting suburbia. Urban design solutions for redesigning suburbs. Hoboken: J. Wiley \& Sons, Inc.

EEA. (2006). Urban sprawl in Europe. The ignored challenge. Final report.Copenhagen: European Environment Agency.

Ewing, R. H. (1994). Characteristics, causes and effects of sprawl: A literature review. Environmental and Urban Studies. 2. 1-15.

Ewing, R., Bartholomew, K., Winkelma, S., Walters, J., \& Chen, D. (2008). Growing cooler: The evidence on urban development and climate change. Washington DC: Urban Land Institute.

Gilbert, R., \& Perl, A. (2008). Transport Revolutions: Moving people and freight without oil. London: Earthscan.

Gillham, O. (2002). The Limitless City: A Premier on the Urban Sprawl Debate. Washington D.C.: Island Press.

Gordon, P., \& Richardson, H. (1997). Are compact cities a desirable planning goal? Journal of the American Planning Association. 63(1), 95-106. http://dx.doi.org/10.1080/01944369708975727

Graham, A. (2000). Demand for leisure air travel and limits to growth. Journal of Air Transport Management. 6. 109-118. http://dx.doi.org/10.1016/S0969-6997(99)00031-9

Harmaajärvi, I. (2000). EcoBalance model for assessing sustainability in residential areas and relevant case studies in Finland.Environmental Impact Assessment Review. 20. 373-80. 
http://dx.doi.org/10.1016/S0195-9255(00)00048-2

He, J., Bao, C.K., Shu, T.F., Yun, X. Y., Jiang, D., \& Brown, L. (2011). Framework for integration of urban planning, strategic environmental assessment and ecological planning for urban sustainability within the context of China. Environmental Impact Assessment Review. 31(6), 549-560. http://dx.doi.org/10.1016/j.eiar.2010.09.002

Howley, P. (2009). Attitudes towards compact city living: Towards a greater understanding of $\begin{array}{llllll}\text { residential behavior. } & \text { Land } & \text { 79e } & \text { Policy. } & 26 .\end{array}$ http://dx.doi.org/10.1016/j.landusepol.2008.10.004

ICEDD. (2005). Bilan énergétique wallon 2005. Consommations du secteur du logement 2005. Namur : MRW, Direction générale Aménagement des Technologies, de la recherché et de l'Energie-Conception et Réalisation ICEDD asbl, Report. Institut de Conseil et d'Etudes en Développement Durable.

INS. (2005). Atlas de Wallonie. Les Hommes $>$ Noyaux d'habitat (INS). http://sder.wallonie.be/ ICEDD/CAP-atlasWallonie2006/pages/atlas.asp?txt=homNoyaux (accessed in September 2013).

Kints, C. (2008). La rénovation énergétique et durable des logements wallons. Analyse du bâti existant et mise en évidence des typologies de logements prioritaires. Université Catholique de Louvain-La-Neuve, Architecture \& Climat.

Marique, A. F., \& Reiter, S. (2012a). A Method to Evaluate the Energy Consumption of Suburban Neighbourhoods. HVAC\&R Research. 18(1-2), 88-99.

Marique, A. F., \& Reiter, S. (2012b).A method for evaluating transport energy consumption in suburban areas.Environmental Impact Assessment Review. 33, 1-6. http://dx.doi.org/10.1016/j.eiar.2011.09.001

Marique, A-F. (2013).Méthodologie d'évaluation énergétique des quartiers périurbains. Perspectives pour le renouvellement périurbain wallon. (A method to evaluate the energy consumption of suburban neighbourhoods. Prospects for a sustainable suburban renewal in Wallonia).Unpublished Doctoral Thesis, University of Liege, 236p.

Marique, A. F., Dujardin, S., Teller, J., \& Reiter, S. (2013a).Urban sprawl, commuting and travel energy consumption.Proceedings of the Institution of Civil Engineers.Energy. 166, 1-13.

Marique, A. F., Dujardin, S., Teller, J., \& Reiter, S. (2013b). School commuting: the relationship between energy consumption and urban form. Journal of Transport Geography, 26. 1-11. http://dx.doi.org/10.1016/j.jtrangeo.2012.07.009

De Meester, T., Marique, A.-F., De Herde, A., \& Reiter, S. (2013). Impacts of occupant behaviours on residential heating consumption for detached houses in a temperate climate of the northern part of Europe. Energy \& Buildings, 57, 313-323. http://dx.doi.org/10.1016/j.enbuild.2012.11.005

Miet, D., \& Le Foll, B. (2013). Construire dans mon jardin et résoudre la crise du logement. 
Cinq idées-clés pour comprendre la filière BIMBY. Métropolitiques.

Modarres, A. (2009). Book Review. Cities. $27 . \quad$ 122-125. http://dx.doi.org/10.1016/j.cities.2009.11.010

Modarres, A., \& Kirby, A. (2010). The suburban question: Notes for a research program. Cities 27, 114-121. http://dx.doi.org/10.1016/j.cities.2009.11.009

Myung-Jun, M. J., Kim, J. I., Kwon, J. H., \& Jeong, J. E. (2013). The effects of high-density suburban development on commuter mode choice in Seoul, Korea. Cities. 31, 230-238. http://dx.doi.org/10.1016/j.cities.2012.06.016

Nesamani, K. S. (2010). Estimation of automobile emissions and control strategies in India. Science of the Total Environment. 408, 1800-1811. http://dx.doi.org/10.1016/j.scitotenv.2010.01.026

Newman, P., \& Kenworthy, J. R. (1989). Cities and Automobile Dependence: A sourcebook. Aldershot: Gower Publishing Co.

Newman, P., \& Kenworthy, J. R. (1999). Sustainability and Cities: overcoming automobile dependence. Washington DC: Island Press.

Phelps, NA. (2010). Suburbs for nations ? Some interdisciplinary connections in the suburban economy.Cities. 27, 68-76. http://dx.doi.org/10.1016/j.cities.2009.11.005

Pierson, C. (2010). Approche sociologique de l'habitat périurbain.(Societal approach to suburban dwellings).Unpublished master thesis, University of Liège.

Pisarski, A. E. (2006). Commuting in America III. The third national report on commuting patterns and trends. Washington D.C.: Transportation Research Board,

Riera Pérez, M. G., \& Rey E. (2013). A multi-criteria approach to compare urban renewal scenarios for an existing neighbourhood. Case study in Lausanne (Switzerland).Building and Environment. 66, 58-70. http://dx.doi.org/10.1016/j.buildenv.2013.03.017

Rice L. (2012). Retrofitting suburbia: Is the compact city feasible? Urban Design and Planning. 163(4), 193-204. http://dx.doi.org/10.1680/udap.2010.163.4.193

Sayce, S., Walford, N., \& Garside, P. (2012). Residential development on gardens in England: Their role in providing sustainable housing supply. Land Use Policy. 29(4), 771-80. http://dx.doi.org/10.1016/j.landusepol.2011.12.002

Da Silva, A. N. R., Costa, G. C. F., \& Brondino, N. C. M. (2007). Urban sprawl and energy use for transportation in the largest Brazilian cities. Energy for Sustainable Development. 11(3), 44-50. http://dx.doi.org/10.1016/S0973-0826(08)60576-1

Steemers, K. (2003). Energy and the city: density, buildings and transport. Energy and Buildings. 35(1), 3-14. http://dx.doi.org/10.1016/S0378-7788(02)00075-0

Tachieva, G. (2010). Sprawl repair manual. Washington D.C: Island Press. 
UTF. (1999).Towards an Urban Renaissance. London: Routledge, Queen's Printer and Controller of HMSO.

Vanneste, D., Thomas, I., \& Goosens, L. (2007). Le logement en Belgique. Report SPF Economie et Statistique. Brussels : SPF Politique Scientifique.

Whitehand, J. W. R., \& Larkham, P. J. (1991). House building in the back garden: reshaping suburban townscapes in the Midlands and South East England. Area 8, 57-65.

Williams, K., Gupta, R., Hopkins, D., Gregg, M., Payne, C., Joynt, J., Smith, I., \& Bates-Brkljac, N. (2013). Retrofitting England's suburbs to adapt to climate change. Building Research \& Information. 41(5), 517-531. http://dx.doi.org/10.1080/09613218.2013.808893

Yaping, W., \& Min, Z. (2009). Urban spill over vs. local urban sprawl: Entangling land-use regulations in the urban growth of China's megacities. Land Use Policy. 26, 1031-1045. http://dx.doi.org/10.1016/j.landusepol.2008.12.005

Young, W., Bowyer, D., \& Naim, R.J. (1996). Modeling the environmental impact of changes in urban structure.Computers, Environment and Urban Systems. 20, 313-26. http://dx.doi.org/10.1016/S0198-9715(96)00024-5

\section{Copyright Disclaimer}

Copyright for this article is retained by the author(s), with first publication rights granted to the journal.

This is an open-access article distributed under the terms and conditions of the Creative Commons Attribution license (http://creativecommons.org/licenses/by/3.0/). 